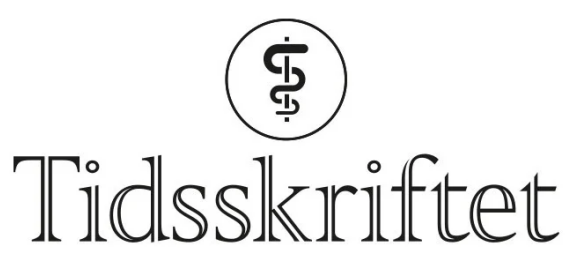

DEN NORSKE LEGEFORENING

\title{
Selvmord blant leger
}

\author{
LEGELIVET
}

ERLEND HEM

erlend.hem@medisin.uio.no

Erlend Hem er instituttsjef ved LEFO - Legeforskningsinstituttet og professor ved Universitetet i Oslo.

\section{I de siste årene er det publisert flere studier om selvmord blant leger. Funnene gir grunn til optimisme.}

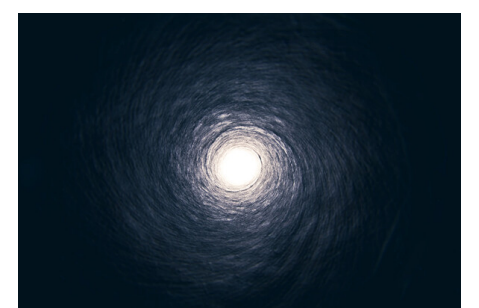

Illustrasjon: sdominick/iStock

Tradisjonelt har leger hatt forhøyet selvmordsrate (1). Men nyere studier tyder på at dette er i ferd med å endre seg. I en oversiktsartikkel fra 2019 inkluderte forfatterne 47 studier av selvmord blant leger, og 25 av dem inngikk i en metaanalyse (2). Samlet standardisert mortalitetsratio (SMR) var 1,44 (95\% konfidensintervall (KI) 1,16 til 1,72). Kvinnelige leger hadde høyere risiko enn menn, og amerikanske leger hadde høyere risiko enn leger i resten av verden. Selvmordsratene falt over tid, særlig i Europa. Funnene indikerte at anestesiologer, psykiatere, allmennleger og generelle kirurger kunne være mer utsatt enn andre (므).

En oversiktsartikkel fra 2020, som omfattet 32 artikler i den systematiske oversikten og ni i metaanalysen, viste en signifikant høyere standardisert mortalitetsratio (1,46; 95 \% KI 1,02 til 1,91) for selvmord blant kvinnelige leger enn andre kvinner (3). Tilsvarende ratio for mannlige leger var signifikant lavere sammenlignet med andre menn. Både for menn og kvinner var selvmordstallene lavere etter 1980.

\section{«Både for menn og kvinner var selvmordstallene lavere etter 1980»}

En fersk studie fra USA omfattet 159 ooo selvmord i National Violent Death Reporting System i perioden 2007-18. Det var registrert 2374 selvmord blant sykepleiere og 857 blant leger. Samlet var selvmordsrisikoen signifikant høyere for sykepleiere enn i den øvrige befolkningen, men ikke for leger (4.). 
Høsten 2021 publiserte The Lancet både en empirisk artikkel (5) og en lederartikkel (ㅁ) om psykiske lidelser og selvmord blant leger. I USA dør én lege i selvmord hver dag. Forfatterne peker på en fremvoksende konsensus om at visse deler av den medisinske utdanningen, arbeidsforholdene og organisasjonsstøtten er uakseptable (5). Forfatterne antyder at forholdene kan ha blitt forverret under pandemien.

\section{Studier av norske leger}

Funnene i de internasjonale studiene samsvarer med norske data. I en studie for perioden 1960-200o ble det registrert 111 selvmord blant norske leger (11). I løpet av denne 40årsperioden økte selvmordsraten fra 1960-årene til 1980-årene, for så å falle i 1990-årene. Men selv om utviklingen var positiv, var selvmordsraten i 1990-årene fremdeles dobbelt så høy blant kvinnelige leger som blant andre kvinner (1). Vi har imidlertid ikke tall etter år 200o, og Legeforskningsinstituttet planlegger en oppfølgingsstudie for å undersøke utviklingen de siste 20 årene.

Forfatterne i The Lancet påpeker at leger generelt har vært dårlige til å søke hjelp (5). I Norge finnes to lavterskeltilbud der leger som opplever påkjenninger, kan søke råd og veiledning. I alle fylker er det oppnevnt støttekolleger som er lett tilgjengelige for samtale, og leger fra hele landet kan søke hjelp ved Ressurssenteret Villa Sana ved Modum Bad (1).

\section{REFERENCES}

1. Hem E. Selvmord blant leger. Tidsskr Nor Legeforen 2015; 135:305. [PubMed][CrossRef]

2. Dutheil F, Aubert C, Pereira B et al. Suicide among physicians and health-care workers: A systematic review and meta-analysis. PLoS One 2019; 14: e0226361. [PubMed][CrossRef]

3. Duarte D, El-Hagrassy MM, Couto TCE et al. Male and female physician suicidality: a systematic review and meta-analysis. JAMA Psychiatry 2020; 77: 587-97. [PubMed][CrossRef]

4. Davis MA, Cher BAY, Friese CR et al. Association of US nurse and physician occupation with risk of suicide. JAMA Psychiatry 2021; 78: 1-8. [PubMed][CrossRef]

5. Harvey SB, Epstein RM, Glozier N et al. Mental illness and suicide among physicians. Lancet 2021; 398: 920-30. [PubMed][CrossRef]

6. Medical professionalism and physician wellbeing. Lancet 2021;398: 817. [PubMed][CrossRef]

Publisert: 21. februar 2022. Tidsskr Nor Legeforen. DOI: 10.4045/tidsskr.22.0054

(C) Tidsskrift for Den norske legeforening 2023. Lastet ned fra tidsskriftet.no 26. april 2023. 